\title{
Tricuspid valve tissue in the left ventricular outflow tract following ventricular septal defect repair
}

\author{
Gregory James Skinner, Suhair Omar Shebani
}

East Midlands Congenital Heart Centre, Leicester Hospitals NHS Trust, Leicester, Leicestershire, UK

\section{Correspondence to} Dr Gregory James Skinner, g.skinner@me.com

Accepted 16 April 2015
CrossMark

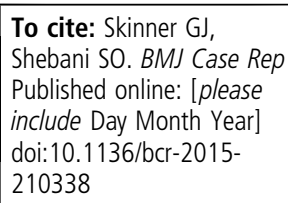

\section{DESCRIPTION}

We present a case of a 28-year-old woman who was born with a ventricular septal defect (VSD) and who was initially treated by pulmonary artery (PA) banding at the age of 5 months, followed by PA band removal and VSD repair at the age of 17 months. She was referred by her local cardiology team to the adult congenital cardiology team due to the appearance of tissue in the left ventricular outflow tract (LVOT). This was not causing any symptoms, but due to thromboembolic concerns, she was started on aspirin.

The operation note documents: "it was necessary to use quite a lot of the tricuspid leaflet to completely close the defect superiorly". Owing to poor transthoracic windows, we arranged for the patient to undergo a three-dimensional transoesophageal echocardiogram to help to delineate the lesion.

The TOE demonstrates two folds of tissue in the posterior LVOT, $14 \mathrm{~mm}$ below the aortic valve. Using 3D multiplane reformatting, it was possible to see the anatomical relationship of this tissue to the septal tricuspid valve leaflet, and the area where it was used to patch over the VSD (figure 1). This

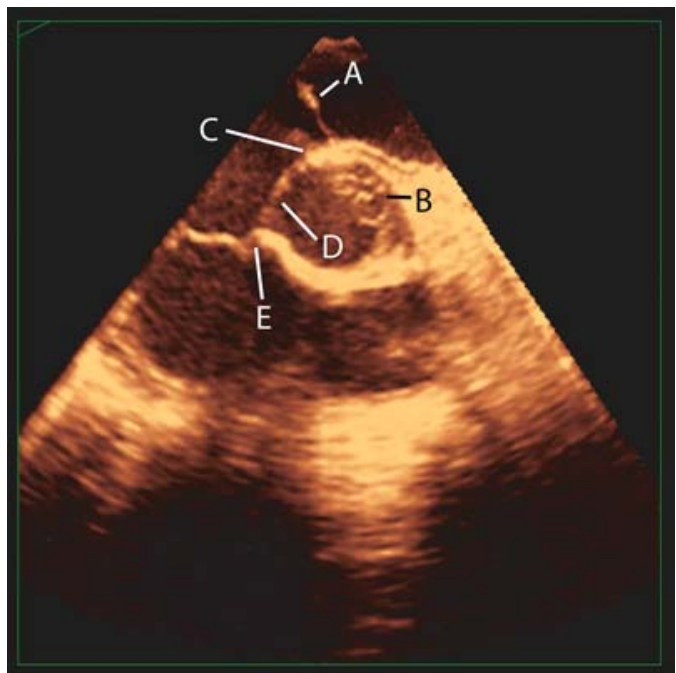

Figure 1 Multi-plane reformatting of the left ventricular outflow tract (LVOT) from a three-dimensional transoesophageal echocardiogram volume. (A) inter-atrial septum, (B) aneurysmal tissue in the LVOT, (C) original hinge point of the septal tricuspid valve leaflet, (D) portion of the septal tricuspid valve leaflet used to close the ventricular septal defect (D), (E) small remaining portion of the septal tricuspid valve leaflet coapting with the anteriosuperior leaflet. was not causing obstruction at rest or on isoprenaline infusion, and is being treated conservatively. The 3D volume reconstruction allows visualisation of the entirety of the LVOT, aiding assessment and understanding of anatomical relationships (videos 1 and 2).

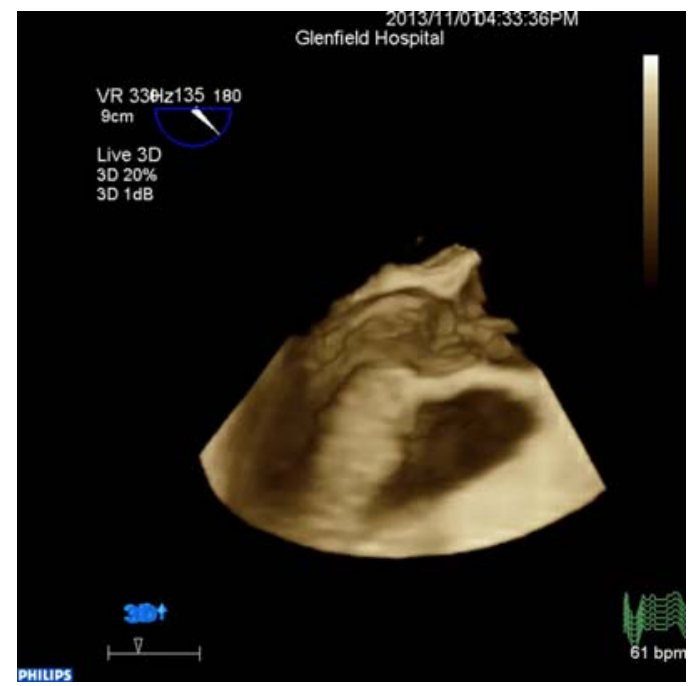

Video 1 Three-dimensional transoesophageal echocardiogram volume rendering of the left ventricular outflow tract demonstrating a long axis view.

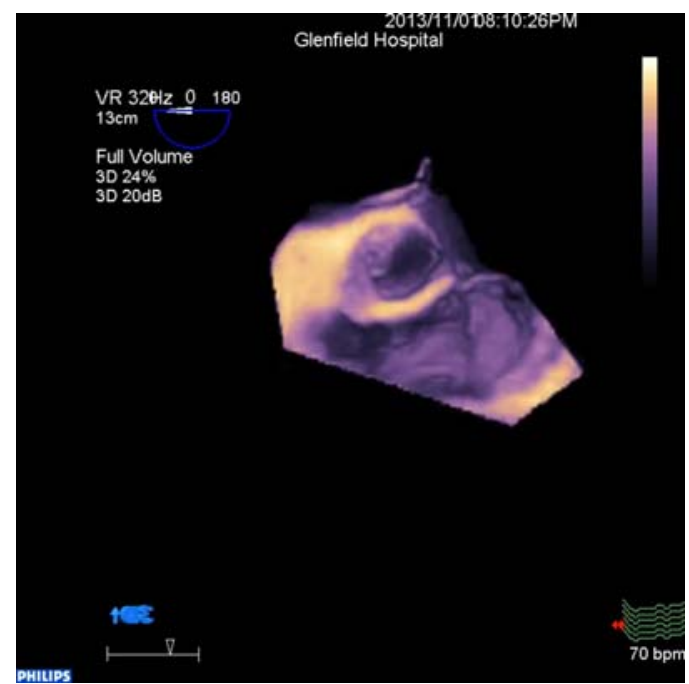

Video 2 Three-dimensional transoesophageal echocardiogram volume rendering of the left ventricular outflow tract demonstrating a short axis view. 


\section{Learning points}

- There are many causes of subaortic obstruction, including previous surgical intervention on the ventricular septum.

- Transoesophageal echocardiography with three-dimensional reconstruction allows much easier and more accurate assessment of anatomically complex lesions.

- Using multi-plane reformatting allows the generation of optimum imaging planes, which is not possible using conventional two-dimensional echocardiography.
Twitter Follow Gregory Skinner at @gjskinner

Competing interests None declared.

Patient consent Obtained.

Provenance and peer review Not commissioned; externally peer reviewed.

Copyright 2015 BMJ Publishing Group. All rights reserved. For permission to reuse any of this content visit http://group.bmj.com/group/rights-licensing/permissions.

BMJ Case Report Fellows may re-use this article for personal use and teaching without any further permission.

Become a Fellow of BMJ Case Reports today and you can:

- Submit as many cases as you like

- Enjoy fast sympathetic peer review and rapid publication of accepted articles

- Access all the published articles

- Re-use any of the published material for personal use and teaching without further permission

For information on Institutional Fellowships contact consortiasales@bmjgroup.com

Visit casereports.bmj.com for more articles like this and to become a Fellow 